\section{The Exmoor Earthquake of September Io.}

FARLY in the morning of Friday, September ro, E three slight earthquakes were felt in North Devon in the district between Morte Bay and Exmoor Forest. The frrst occurred at about 12.15 a.m., and this was followed about an hour later by two slighter shocks separated by an interval of ten minutes. Though it is reported that part of a chimney was dislodged at East Down, and that the light at Bull Point lighthouse was extinguished, it is doubtful if the intensity of the shock at any place exceeded the degree 4 of the Rossi-Forel scale.

The chief interest of the earthquake lies in its connection with a similar, but slightly stronger, shock which occurred on January 23, 1894 (Geol. Mag., vol. iii., I896, pp. 553-56). This earthquake disturbed an area 30 miles long, extending from llfracombe to about 2 miles east of Dulverton, and $16 \frac{1}{2}$ miles wide, the whole area containing about 389 square miles. The centre of the inner isoseismal (intensity 4) was half a mile south-west of Simonsbath. From the dimensions and relative positions of the isoseismal lines it was inferred that the earthquake was due to a fault passing close to Simonsbath, running in the direction E. $22^{\circ} \mathrm{S}$., and hading to the south-a position which agrees almnst exactly with that of the northern boundary fault of the Morte Slates. The length of the fault-displacement was probably about ro miles.

From the accounts so far received it appears that the disturbed area of the recent earthquake is shifted to the west. It is about 22 miles long, I $2 \frac{1}{3}$ miles wide, and contains about 230 square miles. The centre lies half a mile north of East Down and a mile south of the northern boundary fault of the Morte Slatesthat is, on its downthrow side. The length of the seismic focus was about 8 miles, with its centre ro miles west of that of the earthquake of 1804 . The points of interest are (I) that, as is so often the case in British earthauakes, the epicentre migrated to the west, and (2) that the lengths of the two foci and the distance between their centres were roughly equal to that which separates the epicentres of British twin earthquakes.

C. Davison.

\section{Aids to Forecasting. ${ }^{1}$}

A LONG-FELT want of the weather forecaster has $A$ been a methodical classification of weather types associated with the various weather conditions which present themselves. The weather-chart commonly offers a picture familiar enough to the forecaster, but there is much connected with the movement and development which depends upon the bounding conditions. A low-pressure system or depression when appearing off our south-west coasts may have a clear path to the north-eastward, the high-pressure system in its front giving way to its progress. On the other hand, the high-pressure system or anticyclone may be well established and may maintain its ground, thus compelling the advancing disturbance to adapt its track to the situation-a feature of no uncommon occurrence, but one offering considerable difficulty to the work of the forecaster.

Lt.-Col. Gold has made a good attempt to classify the different types of weather which present themselves, and it seems an advance on any previous effort in this direction. The memoir is not hampered by mathe-

1 "Types of Pressure Distribution. with Notes and Tahles for the
Fourteen Years ron5-18." Pv E. Golf. Meteornlogical Office. GeoFourteen Years ron5-18." Pv E. Golf, Meteornlogical Office. Geo-
physical Memoirs, No. 16. (Published by the Air Ministry.) Price 2s. $6 d$. NO. 2656 , VOL. IO6] maties, and is the outcome of a classification and analysis made by the Meteorological Section, R.E., in France during the late war. It is an effort to supply the forecaster when in doubt with reference to some previous situations of a similar character, so that he may see what developments occurred.

Forecasting is admitted to be a matter of experience which is not always very lengthy. Fifteen types and sub-types have been selected, and are graphically shown in the diagrams. The controlling feature in the type is the distribution of atmospheric pressure, and especially the position of the anticyclone. The Daily Weather Charts for fourteen years, $1905^{-18}$, have been analysed according to these types and are classified by months. The results are given in tables, and the forecaster, having drawn his chart, can see to which type it most nearly corresponds, and then look up the dates in the corresponding month on which the type previously occurred. On reference to the Daily Weather Charts for these days he will be able to trace the later developments.

The type-frequency is given in a table for the several months on the totals for fourteen years, which shows clearly the preference of different types for the separate seasons. The essential weather features associated with each type are clearly set out and relate primarily to the winds and weather of NorthEast France and Flanders, although applying also to the conditions over the British Isles.

C. $\mathrm{H}$.

\section{American Work in Genetics.}

THE increasing intricacy of genetic problems and the volume of contributions from American investigators are notable features of present-day biology. Selection of a few recent papers will indicate the way in which genetic experiment is permeating many fields of biological research.

Dr. F. B. Sumner is continuing his studies of the Californian races of the deer-mouse, Peromyscus maniculatus, and in a paper on geographic variation and Mendelian inheritance (Journ. Exptl. Zool., vol. xxx., No. 3) reaches conclusions which, if substantiated by further work, will be of great interest. The subspecies studied are rubidus, which occurs near the coast northwards from San Francisco Bay; Gambeli, a coast-form south of the bay; and sonoriensis, a desert form from the interior of Southern California. Wild mice were trapped from eight stations within these areas, and caged mice are also being extensively bred. Significant racial differences are found in respect to mean length of skull, ear, foot, pelvis, femur, and tail, width of the dorsal tail stripe, colour of pelage, pigmentation of feet, and number of tail vertebræ. Local differences also occur within the range of the same sub-species. Mutations have been described which show Mendelian inheritance, but in hybrids between geographic races it is claimed that the result is a blend, with very little evidence of later segregation.

Among the numerous genetic studies of extra bristles in Drosophila, that of MacDowell has been most extensive. In two of his latest papers (Journ. Exptl. Zool., vol. xxiii., No. I, and vol. xxx., No. 4) he has further analysed the effects of selection on the number of bristles. After selection for a high number through several generations, reverse selection was found to be impossible, except after crossing with the normal type, which has four bristles. One main factor determines a monohybrid ratio in crosses with normal flies, but there is no dominance in the ordinary sense, and there are additional genetic differences between flies having extra bristles. Studies by Payne 
indicate the presence of one bristle factor in the sex chromosome and another in the third group, but the exact relation of these to the increase in number of oristles has not been determined. The environment also influences the number of bristles which appear. In MacDowell's experiments forty-nine generations were bred, and it was found that in a uniform environment selection had no effect after the thirteenth generation; statistical methods show that selection failed to shift the modal condition, and no mutations occurred during the experiments.

In a study of the effects of alcohol on white rats, the same author (Proc. Nat. Acad. Sci., vol. iii., p. 577) finds that alcoholised rats showed a considerable falling off in the weight of their offspring, and a still greater loss in fecundity. 'Twenty-nine pairs of normal rats produced three hundred young in the same time that thirty alcoholised pairs produced one hundred and eight young. He also (Proc. Soc. Exptl. Biol, and Med., vol. xvi., p. 125) finds that the children and grandchildren of parents which had been treated with alcohol for two months before the birth of their young were less apt than the controls in learning to run a maze or to make a multiple choice.

The I eguminosæ are well known to have usually compound leaves, but several genera have unifoliolate varieties, or even species. Blakeslce (Journal of Heredity, April, I9I9) describes such a form arising as a mutation in the Adzuki bean (Phaseolus angularis). His studies of Datlira (Blakeslee and Avery, Journal of Heredity, March, IQI9) have disclosed a number of new forms differing from the type in shape of capsule, foliage, and other characters. They transmit their characters as a complex, chiefly through the female, and in one instance a distinct new species seems to have arisen which breeds true, but appears to be sterile in crosses with the parent species.

\section{R. R. G.}

\section{Increase of Population-a Warning.}

PROF. E. M. EAST has much that is important in his address as retiring president of the $\Lambda$ merican Society of Naturalists, meeting at Princeton (Scientific Monthily, vol. x., 1920, pp. 603-24). At present there are about 1700 million people, with an annual increase of between 14 and 16 millions. The white race is increasing much more rapidly than the yellow or the black. China's 300 million population is practically stationary. With the exception of France, few white peoples are increasing at a less rate than Io per thousand. It is true that in most of the civilised countries of the world the birth-rate is slowly but steadily decreasing, but the result is not what many would have us believe. Where the birth-rate is low, the death-rate is low, except in France. Prof. East predicts that, owing to the steadily increasing development of preventive medicine, the decrease in the birth-rate will have no great effect on the natural increase in the world for many vears to come. If the rate of increase actually existent during the nineteenth century in the United States should continue, within the span of life of the grandchildren of persons now living the States will contain more than a billion inhabitants. "Iong before this eventuality the struggle for existence in thase portions of the world at present more densely nopulated will be something beyond the imagination of those of us who have lived in a time of plenty." The law of diminishing returns is even now in operation in a comparatively new. country like America, thought to be supplied with inexhaustible riches. Prof. East considers in detail what may be done by improved utilisation of energies, No. 2656 , voL. IO6] improved agriculture, improved breeding, and so on; but he is not sanguine. To the criticism that he has not allowed for the "immense possibilities in the way of utilising sea food," he responds with vigour. The cloud grows denser when it is noticed that the birthrate of the foreign population of the United States, coming largely now from eastern and southern Europe, is so much greater than that of the Anglo-Saxon stock (to which, it is claimed, most of the superior types belong) that within a century the latter will be but a fraction of the whole. Prof. East looks forward to severe restriction of immigration; the spread of education; equitable readjustment in many economic customs; rational marriage selection which will tend to an increase of the birth-rate in families of high civic value; and among the rank and file a restriction of births commensurate with the family resources and the mother's strength.

\section{Glass Technology.}

$W^{E}$ have received from the Department of Glass Technology, University of Sheffield, a copy of vol. ii. of "Experimental Researches and Reports" published by that department. The papers included have already appeared in the Journal of the Society of Glass Technology. They range over a somewhat wide field of the glass industry, and include papers dealing with bottle-glass and glass-bottle manufacture, chemical glassware, glass for lamp-working purposes, besides accounts of such relevant investigations as the accurate calibration of burette tubes, a simple apparatus for the detection of strain in glass, and the annealing temperatures of lime-soda and magnesiasoda glasses. There are also a paper descriptive of the glass industry of North America and an account of the year's progress in glass research under the auspices of the Glass Research Delegacy. The condition of the glass industry in this country undoubtedly calls for sustained and systematic research, and this contribution of the Department of Glass Technology of the University of Sheffield must be of considerable assistance to what should be a great and national industry. The newly founded Glass Research Association has also an extensive programme of research in the field of what may be called industrial and laboratory glass, and the British Scientific Instrument Research Association is also more particularly concerned with investigations into optical glass. With such a measure of co-operation and co-ordination as the development of the researches shows to be necessarv between these various budies, there is hope that the users of all types of glass in this country mav be able to find a home supply equal, if not superior, to the foreign sources to which. before the war, they perforce had to go for much of the glass they needed.

\section{Rate of Evolution.}

DROF. E. G. CONKLIN discusses (Scientific Monthly, 1920, vol. x., pp. $580-602)$ the difficult question of the rate of evolution, including under evolution (a) diversification of species, (b) more perfect adaptation to the conditions of life, and $(c)$ increasing differentiation and integration, or, more briefly, progress. If the rate of diversification ("divergent evolution") depends upon the number of mutations that appear. Prof. Conklin argues that it should be proportional, other things being equal, to the rate of reproduction. But this 